Державний заклад

«Луганський національний університет імені Тараса Шевченка»

\author{
Є. М. Хриков, О. І. Кравченко, \\ Т. В. Сич, О. М. Птахіна, О. А. Саснко, А. Г. Розсказов, \\ С. В. Іванов, І. С. Паславська, Н. В. Циган
}

\title{
Актуальні проблеми освітнього, публічного та соціального менеджменту
}

Монографія

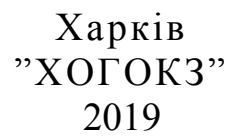


УДК 005[351.851+34.028+37.014.053]-021.121:167.1

DOI 10.26697/9786177089031.2019

A 43

Рекомендовано до друку Вченою радою

ДЗ «Луганського національного університету імені Тараса Шевченка»

(протокол № 5 від 30 листопада 2018 року)

\section{Рецензенти:}

Панасенко Елліна Анатоліївна - доктор педагогічних наук, професор, завідувач кафедри практичної психології ДВНЗ «Донбаський державний педагогічний університет» (м. Слов'янськ);

Дєгтяр Олег Андрійович - доктор наук 3 державного управління, доцент кафедри менеджменту та адміністрування Харківського національного університету міського господарства імені О. М. Бекетова;

Сорочан Тамара Михайлівна - доктор педагогічних наук, професор, Директор Центрального інституту післядипломної педагогічної освіти ДВНЗ «Університет менеджменту освіти» (м. Київ).

Актуальні проблеми освітнього, публічного та соціального А 43 менеджменту : монографія / Є. М. Хриков, О. І. Кравченко, Т. В. Сич, $\begin{array}{lll}\text { О. М. Птахіна, } & \text { О. А. Саєнко, А. Г. Розсказов, } & \text { С. В. Іванов, }\end{array}$ I. С. Паславська, Н. В. Циган. - Х. : ХОГОКЗ, $2019 . \quad-328$ с. doi: $10.26697 / 9786177089031.2019$

ISBN 978-617-7089-03-1

У монографії представлено наукові і практичні здобутки з вивчення актуальних питань освітнього, публічного та соціального менеджменту. Окреслено теоретико-методологічні засади системних досліджень щодо специфіки методології досліджень проблем управління освітою, нормативноправових засад державного управління системою освіти в Україні, стратегічного управління навчальним закладом, фінансового забезпечення освітніх установ.

Видання рекомендоване керівникам закладів різних освітніх та соціальних систем, науковцям, науково-педагогічним працівникам, службовцям установ управління освіти, державним службовцям, соціальним працівникам та всім, хто цікавиться проблемою освітнього, публічного та соціального менеджменту.

За загальною редакцією С. М. Хрикова, О. І. Кравченко. УДК 005[351.851+34.028+37.014.053]-021.121:167.1

(C) Є. М. Хриков, О. І. Кравченко, Т. В. Сич, О. М. Птахіна, О. А. Саєнко, А. Г. Розсказов, Є. В. Іванов, І І. С. Паславська, Н. В. Циган., 2019.

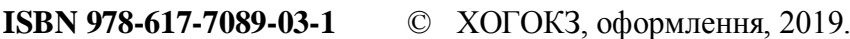




\section{MICT}

Слово до читача

Хриков С. М. Імплементація законів України «Про вищу освіту» та «Про освіту»

Хриков С. М. Державно-громадське управління у сфері освіти

Розсказов А. Г. Нормативно-правові та організаційно-правові засади державного управління системою освіти в Україні

Хриков Є. М., Стан демократизації управління навчальними Іванов $\mathrm{C}$. В. акладами

Сич Т. В. Специфіка методології досліджень проблем управління освітою

Кравченко О. I. Стратегічне управління навчальним закладом

Паславська I. C. Ризик-менеджмент - новітня технологія в системі управління освітою

Саєнко О. А. Теоретичні засади фінансової діяльності закладів освіти

Птахіна О. М. Фінансове забезпечення освітньої діяльності навчальних закладів

Циган Н. B. Управління розвитком професійної компетентності фахівців соціальних закладів в системі безперервної освіти

Відомості про авторів 


\section{Слово до читача}

Сучасний етап розвитку суспільства, глобалізаційні та євроінтеграційні процеси вивели на перший план вивчення проблем освітнього, публічного та соціального менеджменту. Аналіз механізмів освітнього, публічного та соціального менеджменту надає можливість відійти від традиційних зразків управління, від твердих, фіксованих оргструктур, які лише гальмують розвиток навчальних та соціальних закладів.

У монографії містяться наукові і практичні здобутки творчого колективу авторів кафедри публічної служби та управління навчальними й соціальними закладами Д3 «Луганський національний університет імені Тараса Шевченка», більшість яких є представниками наукової школи доктора педагогічних наук, професора С.М.Хрикова. Суттєвий внесок у підготовку монографії здійснено завідувачем кафедри, професором Є.М.Хриковим, який порушує найважливіші питання освітнього та публічного менеджменту, серед яких проблеми імплементації законів України «Про вищу освіту» та «Про освіту» та державно-громадського управління у сфері освіти. Дослідження Є.М.Хрикова 3 державно-громадського управління у сфері освіти доповнено працею А.Г.Розсказова, в якій висвітлено нормативно правові та організаційно-правові засади державного управління системою освіти в Україні. Також Є.М.Хриковим та Є.В.Івановим охарактеризовано стан демократизації управління навчальними закладами як одного 3 актуальних аспектів сучасного освітнього менеджменту. Грунтовним є дослідження Т.В.Сич, в якому розкрито специфіку методології досліджень проблем управління освітою. Нові технології в системі управління освітніми закладами представлено в дослідженнях О.І.Кравченко та І.С.Паславської. Основі аспекти фінансового забезпечення освітніх установ розкрито в працях О.А.Саєнко та О.М.Птахіної. Корисним для керівників соціальних закладів $\epsilon$ дослідження Н.В.Циган щодо управління розвитком професійної компетентності фахівців соціальних закладів в системі безперервної освіти. Монографія грунтується на фундаментальних дослідженнях проблем управління, тому результати поданого дослідження будуть корисними для керівників різних освітніх та соціальних закладів щодо можливості коригування власної управлінської діяльності. 


\section{Відомості про авторів}

Іванов Євген Вікторович - кандидат педагогічних наук, асистент кафедри публічної служби та управління навчальними й соціальними закладами ДЗ «Луганський національний університет імені Тараса Шевченка»

Кравченко Олена Іванівна - доктор педагогічних наук, доцент кафедри публічної служби та управління навчальними й соціальними закладами ДЗ «Луганський національний університет імені Тараса Шевченка»

Паславська Ірина Сергіївна - асистент кафедри публічної служби та управління навчальними й соціальними закладами ДЗ «Луганський національний університет імені Тараса Шевченка»

Птахіна Ольга Миколаївна - кандидат педагогічних наук, доцент кафедри публічної служби та управління навчальними й соціальними закладами Д3 «Луганський національний університет імені Тараса Шевченка»

Розсказов Андрій Григорович - кандидат наук з державного управління, доцент кафедри публічної служби та управління навчальними й соціальними закладами Д3 «Луганський національний університет імені Тараса Шевченка»

Саєнко Ольга Олександрівна - кандидат економічних наук, доцент кафедри публічної служби та управління навчальними й соціальними закладами Д3 «Луганський національний університет імені Тараса Шевченка»

Сич Тетяна Володимирівна - кандидат педагогічних наук, доцент кафедри публічної служби та управління навчальними й соціальними закладами Д3 «Луганський національний університет імені Тараса Шевченка»

Хриков Євген Миколайович - доктор педагогічних наук, професор, завідувач кафедри публічної служби та управління навчальними й соціальними закладами ДЗ «Луганський національний університет імені Тараса Шевченка»

Циган Ніна Валентинівна - аспірант кафедри публічної служби та управління навчальними й соціальними закладами ДЗ «Луганський національний університет імені Тараса Шевченка» 
Наукове видання

\title{
АКТУАЛЬНІ ПРОБЛЕМИ ОСВІТНЬОГО, ПУБЛІЧНОГО ТА СОЦАЛЬНОГО МЕНЕДЖМЕНТУ
}

\author{
Монографія \\ ХРИКОВ Свген Миколайович, \\ КРАВЧЕНКО Олена Іванівна, \\ СИЧ Тетяна Володимирівна, \\ ПТАХІНА Ольга Миколаївна, \\ САСНКО Ольга Олександрівна, \\ РОЗСКАЗОВ Андрій Григорович, \\ ІВАНОВ Свген Вікторович, \\ ПАСЛАВСЬКА Ірина Сергї̈вна, \\ ЦИГАН Ніна Валентинівна \\ ISBN 978-617-7089-03-1 \\ DOI 10.26697/9786177089031.2019
}

Відповідальний випусковий: Є. М. Хриков, О. І. Кравченко Комп'ютерне складання та верстання: I. С. Пипенко

Художній редактор: Ю. Б. Мельник

\section{Видано за рахунок авторів}

Формат 80x64 $64^{1 / 6}$

Гарн. «Тімеs». Папір офс. Друк цифровий.

Ум. друк. арк. 19,1. Зам. № 1-21

Тираж 300 пр.

Державний заклад

«Луганський національний університет імені Тараса Шевченка» Україна, 92703, Луганська обл., м. Старобільськ, пл. Гоголя, 1

Харківська обласна громадська організація "Культура Здоров'я" Україна, 61105, м. Харків - 105, пров. Забайкальський, 6/6. http://publisher.culturehealth.org; тел./факс: (057)775-75-23.

Email: CultureHealth@ukr.net; KOSOCH@gmail.com;

Свідоцтво про державну реєстрацію видавництва ДК № 4387 від 10.08.2012 